\title{
Antibodies Directed against the Pancreatic Islet Cell Plasma Membrane
}

\section{Detection and Specificity}

\author{
Å. Lernmark, T. Kanatsuna, C. Patzelt, K. Diakoumis, R. Carroll, A. H. Rubenstein, and D. F. Steiner \\ Departments of Biochemistry and Medicine, University of Chicago, Chicago, Illinois, USA
}

Summary. Rabbits were immunised with suspensions of viable, insulin-producing islet cells prepared from collagenase-isolated rat or $a b / o b$ mouse pancreatic islets. Antibodies reactive with the surface of dispersed rat islet cells were present in both the rabbit anti-rat and the rabbit anti - ob/ob mouse islet sera as revealed by indirect immunofluorescence or by a radioligandassay using ${ }^{125} \mathrm{I}$-Protein $\mathrm{A}$ as a measure of cell bound IgG. In a competition assay the binding of ${ }^{125}$ I-Protein A was displaced in a concentration dependent manner by non-radioactive Protein A. Maximal displacement was found at concentrations of Protein A higher than $0.1 \mu \mathrm{g}$ added to $10^{5}$ islet cells. Although not always detected by immunofluorescence there was a several-fold increase above normal rabbit serum of ${ }^{125} \mathrm{I}$-Protein A-binding to rat hepatocytes and spleen lymphocytes incubated with the islet cell antisera. Conversely, rabbit antisera against rat spleen lymphocytes or against a rat liver plasma membrane preparation reacted with rat islet cells. The rabbit anti-rat islet cell antiserum was absorbed to both spleen lymphocytes and hepatocytes until there was no binding of ${ }^{125} \mathrm{I}$-Protein $\mathrm{A}$ to either cell type. Islet specific antibodies were still present since this doubly absorbed antiserum induced cell surface immunofluorescence as well as ${ }^{125}$ I-Protein A-binding to rat islet cells. It is concluded that apart from common antigenic determinants immunisation with viable islet cells induces formation of antibodies directed against specific islet cell surface components.

Key words: Pancreatic islet cells, cell suspensions, islet cell surface antibodies, cell surface immunofluorescence, Protein A radioassay, cell surface antigens, autoimmunity, diabetes mellitus.
Circulating pancreatic islet cell antibodies have been demonstrated in patients with insulin-dependent diabetes $[1,2]$ with a prevalence of $60 \%$ more or more during the first year after diagnosis $[3,4]$. These antibodies appear to react with intracellular components and are not specific for B cells [1]. Similar cytoplasmic antibodies are also found in the serum of some patients with asymptomatic or latent diabetes $[5,6]$ or in mild diabetics treated with oral hypoglycaemic agents [7] raising the question as to whether these antibodies are actually involved in the pathological process leading to the loss of B cell function.

Using suspensions of viable rat islet cells cell-surface antibodies have been demonstrated in sera from many insulin-dependent diabetic children [8]. In the present study experiments were therefore undertaken to investigate the antigenic characteristics of islet cells. By indirect immunofluorescence or by a sensitive and quantitative radioligandassay, specific to cell-bound IgG, it was tested whether rabbits immunised with suspensions of viable cells from isolated rat and mouse islets developed islet cell surface antibodies.

\section{Materials and Methods}

\section{Isolation of Pancreatic Islets}

Islets of Langerhans were isolated from the pancreas of SpragueDawley strain rats $(200-250 \mathrm{~g})$ and of 8 months old female C57BL/6J ob/ob mice (Jackson-Laboratory, Bar Harbor, Maine). The procedure used is a modification of the methods of Moskalewski [9] and Lacy and Kostianovsky [10] using collagenase (crude collagenase, type IV, Worthington Biochemical Corp., Freehold, New Jersey, U.S. A.) to digest the pancreatic parenchyma as previously described in detail $[11,12]$. 
Table 1. Rat islet cells in suspension

\begin{tabular}{llllll}
\hline Method & $\begin{array}{l}\text { Enzyme } \\
\text { treatment }\end{array}$ & $\begin{array}{l}\text { No. of } \\
\text { experiments }\end{array}$ & $\begin{array}{l}\text { No. of cells } \\
\text { in suspension } \\
\text { (x 105 cells/rat) }\end{array}$ & $\begin{array}{l}\text { \% single } \\
\text { cells }\end{array}$ & $\begin{array}{l}\% \text { Trypan blue } \\
\text { negative cells }\end{array}$ \\
\hline I & None & 6 & $2.1 \pm 0.2$ & $37 \pm 1$ & $83 \pm 1$ \\
& $\begin{array}{l}\text { Collagenase } \\
\text { Collagenase and } \\
\text { hyaluronidase }\end{array}$ & 6 & $1.2 \pm 0.4$ & $50 \pm 6$ & $84 \pm 5$ \\
& $\begin{array}{l}\text { Collagenase } \\
\text { Collagenase and }\end{array}$ & 18 & $0.8 \pm 0.1$ & $50 \pm 3$ & $97 \pm 2$ \\
& 6 & $2.1 \pm 0.1$ & $58 \pm 1$ & $94 \pm 0.2$ \\
& hyaluronidase & & $2.5 \pm 0.3$ & $64 \pm 4$ & $94 \pm 3$ \\
\hline
\end{tabular}

Preparation of cell suspension from roughly $1-2 \times 10^{3}$ islets isolated from $6-8$ rats. Before mechanical disruption into cell suspensions the islets were incubated with collagenase alone or combined with hyaluronidase. Mean values \pm SEM for the indicated number of experiments

\section{Preparation of Islet Cell Suspensions}

Suspensions of islet cells were prepared by mechanical dispersion of isolated islets $[8,11]$. In short, the isolated islets were separated from the collagenase-digest by Ficoll-gradient centrifugation and were then individually chosen by the aid of a stereomicroscope. The islets were kept in Swim's S-77 medium (Grand Island Biological Company, Grand Island, New York) supplemented with $5 \mathrm{mmol} / \mathrm{l}$ sodium bicarbonate, $50 \mu \mathrm{mol} / \mathrm{l}$ L-cysteine, $5 \mathrm{mmol} / \mathrm{l}$ L-glutamine, $56 \mu \mathrm{mol} / 1$ phenol red, 100,000 units $/ 1$ penicillin, $10 \mathrm{mg} / 1$ streptomycin, $20 \mathrm{mmol} / \mathrm{l} \mathrm{N}$-hydroxyethyl-piperazine- $\mathrm{N}$ '2-ethane-sulphonic acid (Hepes), $1 \mathrm{mmol} / \mathrm{l}$ ethylene-glycolbis(oxy-ethylenenitrilo)-tetraacetic acid (EGTA) and $10 \mathrm{~g} / \mathrm{l}$ bovine serum albumin (BSA, Miles Laboratories Inc., Kankakee, II1.). The medium was adjusted to $\mathrm{pH} 7.4$ and the mixture without EGTA is referred to as Swim's medium.

Roughly $1-2 \times 10^{3}$ islets from $6-8$ rats were incubated in $2 \mathrm{ml}$ Swim's medium with $0.1 \mathrm{mmol} / 1 \mathrm{CaCl}_{2}, 12.5$ units $/ \mathrm{ml} \mathrm{DNAse}$ (Worthington) and either $2 \mathrm{mg} / \mathrm{ml}$ collagenase (Worthington, type IV, 160-179 U/mg alone or combined with $1 \mathrm{mg} / \mathrm{ml}$ hyaluronidase (Sigma Chemical Co., St. Louis, Mo., U. S. A, 370 units $/ \mathrm{mg}$ ) (Table 1). The incubations were carried out in coated glass scintillation vials for $30 \mathrm{~min}$ at $37^{\circ} \mathrm{C}$ with slow shaking ( 90 cycles $/ \mathrm{min}$ ) and was terminated by the addition of $10 \mathrm{ml}$ Swim's medium supplemented with $10 \mathrm{~g} / 1 \mathrm{BSA}$ and $1 \mathrm{mmol} / 1$ EGTA. The islets were pelleted by centrifugation $(50 \times \mathrm{g}$ for $5 \mathrm{~min}$.), re-suspended in Swim's medium containing BSA and EGTA, further supplemented with $125-600$ units/ml DNAse, and allowed to stand at room temperature for $15 \mathrm{~min}$. The islets were disrupted by brief mechanical shaking [11]. In method I (Table 1) the resulting cell suspension was layered on $10 \mathrm{ml} 40 \mathrm{~g} / 1 \mathrm{BSA}$ in Swim's medium and intact cells pelleted by centrifugation for $5 \mathrm{~min}$ at $50 \times \mathrm{g}$.

The additional period of enzyme treatment with either collagenase alone or in combination with hyaluronidase increased the yield of single cells. Exposing the isolated islets to enzymes such as trypsin, ficin or $\beta$-glucosidase combined with collagenase, or to chromatographically purified collagenase alone, had little or no effect on the recovery of single cells as compared with direct mechanical dispersion of freshly isolated islets. In method II (Table 1) the cell suspension was layered on a discontinuous BSAgradient composed from below of $1 \mathrm{ml} 300 \mathrm{~g} / 1 \mathrm{BSA}$ and $10 \mathrm{ml}$ $40 \mathrm{~g} / 1 \mathrm{BSA}$ in Swim's medium. After centrifugation $(50 \times \mathrm{g}$ for $5 \mathrm{~min}$ ) the cells were recovered from the interface between the $300 \mathrm{~g} / 1$ and $40 \mathrm{~g} / 1 \mathrm{BSA}$-layers. Microscopic analysis of the cellpellet obtained in Method II indicated that the increased yield of single cells seemed to be due to a selective removal of clumps. The contaminating exocrine cells were $1.2 \pm 0.3 \%$ (mean \pm SEM for 6 experiments) among the total number of cells at the $300 \mathrm{~g} / \mathrm{l} \mathrm{BSA-}$ interphase while $32 \pm 4 \%$ (14 experiments) of the pelleted cells were exocrine cells. If not otherwise stated, islet cell suspensions were prepared according to Method II after exposing the isolated islets to an additional period with collagenase before the mechanical treatment.

\section{Preparation of Spleen Cells and Hepatocytes}

Rat spleen lymphocytes were prepared from 4-8 rats. Each spleen was minced by scissors in Swim's medium with EGTA (as above) and filtered through nylon mesh to remove remaining pieces of tissue. After washing twice by centrifugation $(5 \mathrm{~min}, 100 \times \mathrm{g})$ in Swim's medium with $40 \mathrm{~g} / 1 \mathrm{BSA}$, the cells were layered onto Ficoll-Paque (Pharmacia, Uppsala, Sweden) and lymphocytes isolated by a single step centrifugation procedure [13]. Rat hepatocytes were prepared as described by Chan [14] and suspended in Swim's medium with $40 \mathrm{~g} / 1 \mathrm{BSA}$.

\section{Immunisation of Rabbits}

Female, New Zealand rabbits (1-2 kg body weight) were immunised with living dispersed islet cells washed in $0.154 \mathrm{~mol} / 1 \mathrm{NaCl}$. All islet cells used for immunisation were prepared from islets collected after the Ficoll-gradient centrifugation. Four rabbits were immunised with rat islet cells and one rabbit with $o b / o b$ mouse islet cells. In a primary injection the cells $\left(0.5-1 \times 10^{6}\right.$ cells) were injected in a volume of $100 \mu$ into a popliteal lymph node on each leg. The lymph node was identified by the subcutaneous injection into each foot of Evans blue dissolved in $0.154 \mathrm{~mol} / \mathrm{l}$ saline $1 \mathrm{~h}$ before surgery [13]. The surgery was carried out after anaesthetising the rabbits with $0.5 \mathrm{ml} / \mathrm{kg}$ body weight Diabutal.

Complete Freund's adjuvant (Difco Laboratories, Michigan) was emulsified in an equal volume of $0.154 \mathrm{~mol} / 1$ saline and $1 \mathrm{ml}$ injected intracutaneously at multiple sites into each hind leg and abdomen. Two intravenous booster injections were given two weeks apart with $0.5-1 \times 10^{6}$ islet cells in $1 \mathrm{ml} 0.154 \mathrm{~mol} / 1 \mathrm{saline}$. The rabbits were bled from the ear artery two weeks after the last booster injection, and the blood allowed to clot overnight at $4{ }^{\circ} \mathrm{C}$. Serum was removed after centrifugation at $4{ }^{\circ} \mathrm{C}$ and stored in aliquots at $-20^{\circ} \mathrm{C}$. Before dilution in Swim's medium or preparation of $\mathrm{IgG}$ all serum samples were heat-inactivated at $56^{\circ} \mathrm{C}$ for 30 min.

Rat spleen lymphocytes were washed twice by centrifugation in $0.154 \mathrm{~mol} / \mathrm{l}$ saline. The cell number was adjusted to $10^{7} \mathrm{cells} / \mathrm{ml}$ and $1 \mathrm{ml}$ injected intravenously into the rabbits' ear. The rabbits were injected once per week for three weeks and then bled one week after the last injection. 


\section{Absorption of Serum}

Aliquots of anti-rat islet cell antiserum $(100-500 \mu l)$ were added to pellets of either living spleen lymphocytes or hepatocytes. The cell preparations represented either approximately, 500-100 $\mu \mathrm{l}$ packed spleen lymphocytes or $500 \mu$ packed hepatocytes. The cells were carefully resuspended in the antiserum and incubated for $4 \mathrm{~h}$ at $4{ }^{\circ} \mathrm{C}$. The antiserum was retrieved by centrifugation at $150 \times \mathrm{g}$ for $3-5 \mathrm{~min}$.

\section{Preparation of Serum Immunoglobulins}

Serum $\operatorname{IgG}$ was partially purified from $200-500 \mu$ l heat-inactivated serum by chromatography in DEAE-Sephadex using a scaled-down modification of the method described by Baumstark et al. [16]. The DEAE-Sephadex columns $(5 \mathrm{ml}$ in disposable syringes) were washed in either $10 \mathrm{mmol} / 1 \mathrm{KH}_{2} \mathrm{PO}_{4} / \mathrm{K}_{2} \mathrm{HPO}_{4}(\mathrm{pH}$ $6.5)$ or $10 \mathrm{mmol} / 1 \mathrm{Hepes}(\mathrm{pH} 6.5)$ buffer. After addition of the serum sample $(200-500 \mu \mathrm{I})$ the columns were eluted with either of the two buffers in $500 \mu \mathrm{l}$ fractions in a total volume of $10 \mathrm{ml}$. Each fraction was read at $280 \mathrm{~nm}$ and the IgG content determined by quantitative immunodiffusion (Miles Research Products Radial Immunodiffusion Kit, Miles Laboratories Inc., Elkhart, Ind.). Peak fractions of $\operatorname{IgG}$ were pooled and stored at $-20^{\circ} \mathrm{C}$. IgG was also isolated by affinity chromatography on protein A-Sepharose [17]. Bound $\mathrm{IgG}$ was eluted with $50 \mathrm{mmol} / 1$ glycerine-HCl-buffer $(\mathrm{pH} 2.8)$ and dialysed against Swim's medium or a $10 \mathrm{mmol} / \mathrm{l}$ Hepes-buffer ( $\mathrm{pH} 7.4$ ) with $0.14 \mathrm{~mol} / \mathrm{l} \mathrm{NaCl}$. Protein A-Sepharose CL-4B was from Pharmacia Fine Chemicals, Uppsala, Sweden.

\section{Insulin Antibodies}

Insulin antibodies were determined by incubating ${ }^{125} \mathrm{I}$-insulin with rabbit antisera at various dilutions. Bound and free radioactive insulin was separated by precipitation with a second antibody [18]. Goat anti-rabbit immunoglobulin serum was from Miles Laboratories, Elkhart, Ind., USA.

\section{Immunofluorescent Test}

Binding of antibodies to the surface of living cells was tested by indirect immunofluorescence. Suspensions of rat islet cells, spleen lymphocytes and hepatocytes were used. Suspensions of cells were incubated in $100 \mu \mathrm{l}$ Swim's medium with $40 \mathrm{~g} / \mathrm{I}$ BSA containing $0.1-50 \mu \mathrm{l}$ fractionated serum. Following incubation at room temperature $\left(23^{\circ} \mathrm{C}\right)$ for $30 \mathrm{~min}$ the cells were washed by adding $10 \mathrm{ml}$ Swim's medium with $40 \mathrm{~g} / 1 \mathrm{BSA}$ (filtered through Millipore filters; $0.45 \mu \mathrm{m})$ and centrifugation for $5 \mathrm{~min}$ at $50 \times \mathrm{g}$. The cell-pellet was resuspended in $100 \mu \mathrm{l}$ fluoresceine isothiocyanate (FITC-)labelled goat anti-rabbit IgG (Miles Research Products, Miles Laboratories Inc, Elkhart, Ind.) diluted 1:15 in Swim's medium with $40 \mathrm{~g} / \mathrm{l} \mathrm{BSA}$ and incubated for $30 \mathrm{~min}$ at room temperature. The cells were then washed as above, resuspended in $10 \mu \mathrm{l}$ Swim's medium with $4 \%$ BSA and mounted on slides. The preparation was sealed with coverslips and Permount ${ }^{\circledR}$ (Fischer Scientific Co., Fair Lawn, N. J.). The cells were finally evaluated by phase contrast and fluorescence microscopy as described previously [8] using a Zeiss microscope equipped with an epi-fluorescence condenser.

\section{Iodination of Protein A}

Protein A (Pharmacia Fine Chemicals, Uppsala, Sweden) was iodinated by a modification of a chloramine-T method [19]. Protein $\mathrm{A}(2 \mu \mathrm{g})$ in $50 \mu \mathrm{l} 0.3 \mathrm{~mol} / \mathrm{l}$ sodium phosphate buffer, $\mathrm{pH} 7.4$, was added to a $1.5 \mathrm{ml}$ Eppendorf plastic test tube together with 2.0 $\mathrm{mCi}$ of $\mathrm{Na}^{125} \mathrm{I}$ (specific activity $>300 \mathrm{mCi} / \mathrm{ml}$ ) (Industrial Nuclear Co., Inc., St. Louis, Mo.). The reaction was initiated by the addition of $20 \mu \mathrm{l} 0.1 \mathrm{mmol} / \mathrm{l}$ chloramine- $\mathrm{T}$ in sodium phosphate buffer and, after gentle shaking for $3 \mathrm{~min}$, stopped by the addition of $5 \mu \mathrm{l}$ $\mathrm{mmol} / \mathrm{l}$ sodium metabisulphide in sodium phosphate buffer and $100 \mu \mathrm{l}$ of $130 \mathrm{mmol} / 1$ borate buffer, $\mathrm{pH} 8.0$ containing $0.5 \%$ BSA (borate-BSA). The labelled Protein A (specific activity $35-40 \mu \mathrm{C}$ / $\mu \mathrm{g}$ ) was immediately subjected to gel filtration on a $0.8 \times 15 \mathrm{~cm}$ superfine Sephadex G-75 column equilibrated in borate-BSA. The ${ }^{125}$ I-protein $\mathrm{A}$ was eluted from the column completely separated from the free iodide and stored in aliquots at $-20^{\circ} \mathrm{C}$.

\section{Protein A-binding Assay}

Cell bound $\mathrm{IgG}$ was estimated in a ${ }^{125} \mathrm{I}$-Protein A-binding assay $[20,21,22]$. Protein A binds specifically to IgG of most classes $[17,20]$. Living cells in duplicate tubes were first incubated for $30 \mathrm{~min}$ in $100 \mu \mathrm{l}$ of various concentrations of serum. After washing by centrifugation $(50 \times \mathrm{g}, 5 \mathrm{~min})$ in $10 \mathrm{ml}$ Swim's medium with $40 \mathrm{~g} / \mathrm{l} \mathrm{BSA}$, the cells were incubated with $100 \mu \mathrm{l}^{125}$ I-Protein A $\left(1-2 \times 10^{5} \mathrm{cpm} /\right.$ tube $)$ for $30 \mathrm{~min}$. The cells were washed twice by centrifugation and finally counted in a gamma scintillation counter. To estimate the amount of cell-bound Protein A, cells were first incubated in $0.5 \%(\mathrm{v} / \mathrm{v})$ serum in Swim's medium with $40 \mathrm{~g} / 1 \mathrm{BSA}$, washed by centrifugation and incubated in $100 \mu \mathrm{l}$ Swim's medium with $40 \mathrm{~g} / \mathrm{l}$ BSA containing 1-1000 ng nonradioactive Protein A. After incubation for 30 min the cells were washed by centrifugation before incubation in $100 \mu{ }^{125}$ I-Protein A. Duplicate determinations were run in each experiment. The coefficient of variation for the individual measurement was below $15 \%$. Results are given as mean values \pm SEM.

\section{Results}

\section{Islet Cell Surface Immunofluorescence}

Table 2 shows that antibodies reactive with the surface of rat islet cells were formed in rabbits immunised with suspensions of viable cells from rat islets or from $\mathrm{B}$ cell islets of the $o b / o b$ mouse. The cell-surface reaction varied in appearance from a dotted pattern to an intense ring-shaped reaction. Intact cells, as judged by phase contrast microscopy, were scored as having either a positive or a negative reaction. The relationship between serum concentration and immunofluorescence is shown in Figure 1. While only a few positive cells were observed after exposure to $1 \%(\mathrm{v} / \mathrm{v})$ anti-islet cell antiserum nearly all islet cells were clearly fluorescent after being treated with $5 \%$ $(\mathrm{v} / \mathrm{v})$ islet cell antiserum.

Rabbit antisera against rat spleen lymphocytes and rat liver plasma membranes also produced cellsurface immunofluorescence on islet cells (Table 2). However, there was no immunofluorescent reaction on rat islet cells exposed to sera from normal rabbits or rabbit antisera prepared against bovine serum albumin or glucagon. It should be noted that insulin antibodies could not be detected in either the rat islet cell or the $a b / a b$ mouse islet cell antiserum. 
Table 2. Cell surface immunofluorescence on rat islet cells

\begin{tabular}{|c|c|c|}
\hline Rabbit antiserum & Serum preparation & $\begin{array}{l}\text { Islet cell surface } \\
\text { immunofluores- } \\
\text { cence }\end{array}$ \\
\hline \multirow[t]{3}{*}{ Anti-rat islet cell } & $\begin{array}{l}\text { Serum }(0.5-50 \% \\
\mathrm{v} / \mathrm{v})\end{array}$ & + \\
\hline & $\begin{array}{l}\text { IgG (DEAE- } \\
\text { Sephadex) }\end{array}$ & + \\
\hline & $\begin{array}{l}\text { IgG (Protein A- } \\
\text { Sepharose) }\end{array}$ & + \\
\hline \multirow{2}{*}{$\begin{array}{l}\text { Anti-ob/ob-mouse } \\
\text { islet cell }\end{array}$} & Serum $(5-50 \%, v / v)$ & + \\
\hline & $\begin{array}{l}\text { IgG (DEAE- } \\
\text { Sephadex) }\end{array}$ & + \\
\hline \multirow[t]{3}{*}{ Anti-rat spleen cells } & Serum $(50 \%, v / v)$ & + \\
\hline & $\operatorname{IgG}(\mathrm{DEAE}-$ & + \\
\hline & Sephadex) & $\cdot$ \\
\hline $\begin{array}{l}\text { Anti-rat liver } \\
\text { plasma membrane }\end{array}$ & $\operatorname{Serum}(50 \%, v / v)$ & + \\
\hline $\begin{array}{l}\text { Anti-bovine serum } \\
\text { albumin }\end{array}$ & $\operatorname{Serum}(50 \%, \mathrm{v} / \mathrm{v})$ & - \\
\hline $\begin{array}{l}\text { Anti-porcine } \\
\text { glucagon }\end{array}$ & $\operatorname{Serum}(50 \%, \mathrm{v} / \mathrm{v})$ & - \\
\hline
\end{tabular}

Suspensions of rat islet cells were incubated with serum or IgG purified by DEAE-Sephadex or Protein A-Sepharose chromatography. Islet cell surface immunofluorescence was evaluated after exposing the cells to a fluorescent second antibody in an indirect immunofluorescence test. Each serum was scored after evaluating 50 to 100 cells in coded samples in three different experiments

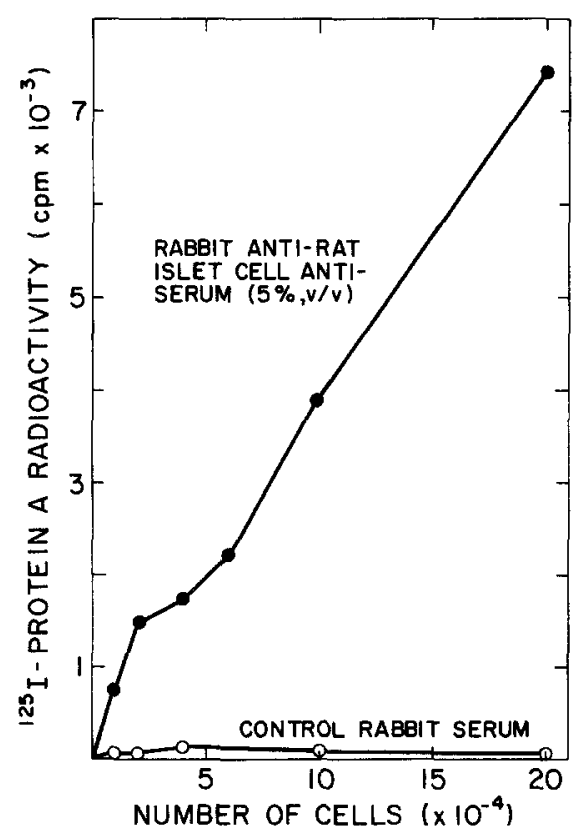

Fig. 2. Binding of ${ }^{125} \mathrm{I}$-Protein $\mathrm{A}$ in relation to the number of rat islet cells exposed to $5 \%(\mathrm{v} / \mathrm{v})$ rabbit anti-rat islet cell antiserum or to $5 \%(\mathrm{v} / \mathrm{v})$ non-immune rabbit serum. Mean values for 3 determinations

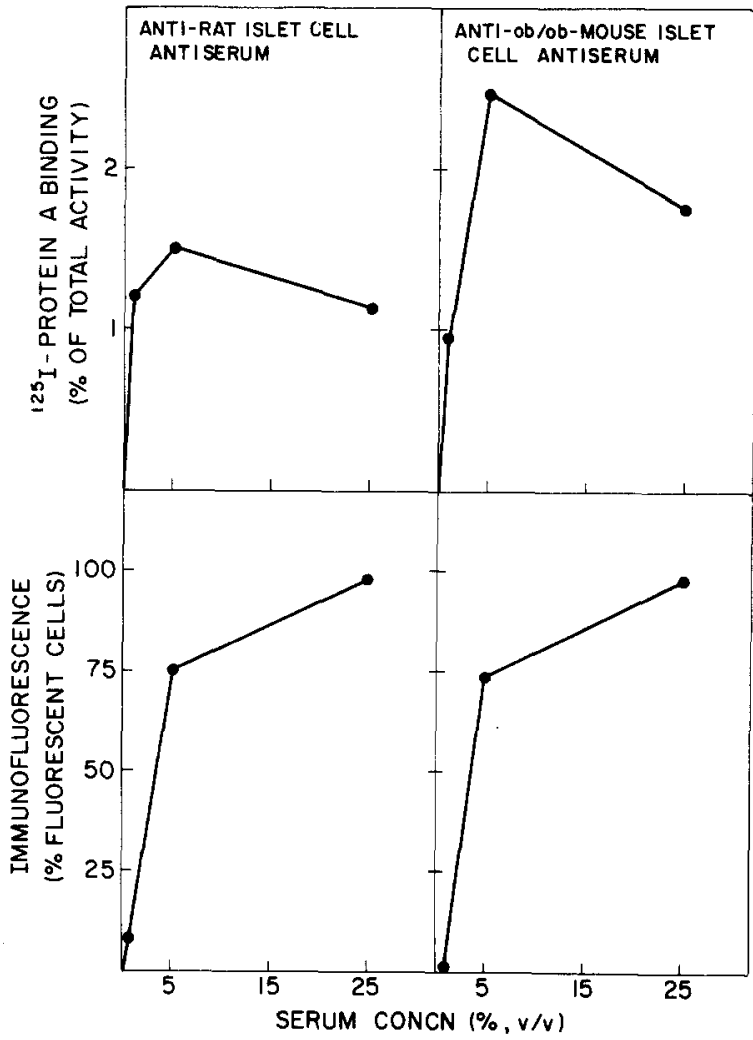

Fig. 1. Cell surface immunofluorescence and Protein A-binding activity on rat islet cells exposed to rabbit anti-rat islet cell or anti$o b / o b$-mouse islet cell antisera. About $10^{5}$ rat islet cells were incubated with serum diluted in Swim's medium supplemented with $40 \mathrm{~g} / 1 \mathrm{BSA}$. After washing by centrifugation the cells were resuspended in either fluoresceinisothiocyanate conjugated antiserum in an indirect immunofluorescence test or in ${ }^{125} \mathrm{I}$-Protein $\mathrm{A}$ in a Protein A-binding assay. The Protein A-binding activity has been corrected for the binding induced by non-immune rabbit serum. Per cent fluorescent cells were calculated after evalutating 100 single cells. Mean values for $2-3$ determinations

\section{Islet Cell Binding of Protein A}

Figure 1 shows the binding of ${ }^{125} \mathrm{I}$-Protein $\mathrm{A}$ to islet cell suspensions previously exposed to various concentrations of either the rabbit anti-rat islet cell or the $o b / o b$ mouse islet cell antisera. Separate experiments indicated that islet cells exposed to $0.1-5 \%$ anti-rat islet cell antiserum bound 4-25 times more ${ }^{125}$ I-Protein $\mathrm{A}$ than cells incubated with normal rabbit serum. There was a linear relationship between the number of islet cells incubated in the anti-rat islet cell antiserum and the subsequent binding of ${ }^{125} \mathrm{I}$ Protein A (Fig. 2).

\section{Binding of Islet Cell Antibodies to Spleen Cells and Hepatocytes}

While the rat islet cell antiserum induced immunofluorescence on both spleen cells and hepatocytes, 
Table 3. Cell surface immunofluorescence on spleen cells and hepatocytes exposed to anti-rat islet cell antisera

\begin{tabular}{lll}
\hline Rabbit antiserum & \multicolumn{2}{c}{ Cell surface immunofluorescence } \\
\cline { 2 - 3 } & Spleen cells & Hepatocytes \\
\hline Anti-rat islet cell & + & + \\
Anti-ob/ob-mouse & - & + \\
islet cell & & + \\
Anti-rat spleen cell & + & + \\
Anti-rat liver & + & \\
plasma membrane & & \\
\hline
\end{tabular}

Suspensions of rat spleen lymphocytes and hepatocytes were incubated at $4{ }^{\circ} \mathrm{C}$ or at room temperature with antiserum. Cell surface immunofluorescence was evaluated after exposing the cells to a fluorescent second antibody in an indirect immunofluorescence test. Each serum was scored after evaluationg 200 to 300 cells in coded samples in three different experiments of each cell type

only the latter cells fluoresced after incubation with the anti-ob/ob mouse islet cell antiserum (Table 3). However, the ${ }^{125}$ I-Protein A-binding assay revealed that both spleen cells and hepatocytes bound antibodies after exposure to either the anti-rat or the anti-ob/ob mouse islet cell antiserum (Fig. 3). It is evident that ${ }^{125} \mathrm{I}$-Protein A-binding is a considerably more sensitive measure of cell surface bound antibodies than is immunofluorescence. Figure 3 also shows the binding of ${ }^{125} \mathrm{I}$-Protein A to hepatocytes and spleen lymphocytes exposed to various concentrations of spleen lymphocyte or liver cell plasma membrane antisera. As compared to non-immune serum the Protein A-binding to lymphocytes was increased by a factor of 36 by the lymphocyte antiserum and in the case of the hepatocytes by a factor of 6. There was a 3-4 fold increase in the binding of Protein A after exposing either hepatocytes or spleen lymphocytes to the liver cell plasma membrane antiserum.

\section{Islet Cell Specific Antibodies}

After absorption to spleen lymphocytes the anti-rat islet cell antiserum still induced cell surface immunofluorescence on both islet cells and hepatocytes. The antiserum was, therefore, absorbed to both spleen lymphocytes and hepatocytes and then tested with the Protein A assay until there was no binding to either lymphocytes or hepatocytes. Islet cell specific antibodies were still present since this doubly-absorbed antiserum induced cell surface immunofluorescence as well as ${ }^{125}$ I-Protein A-binding to rat islet cells (Fig. 4). In order to estimate the amount of Protein A-reactive IgG bound per cell, the

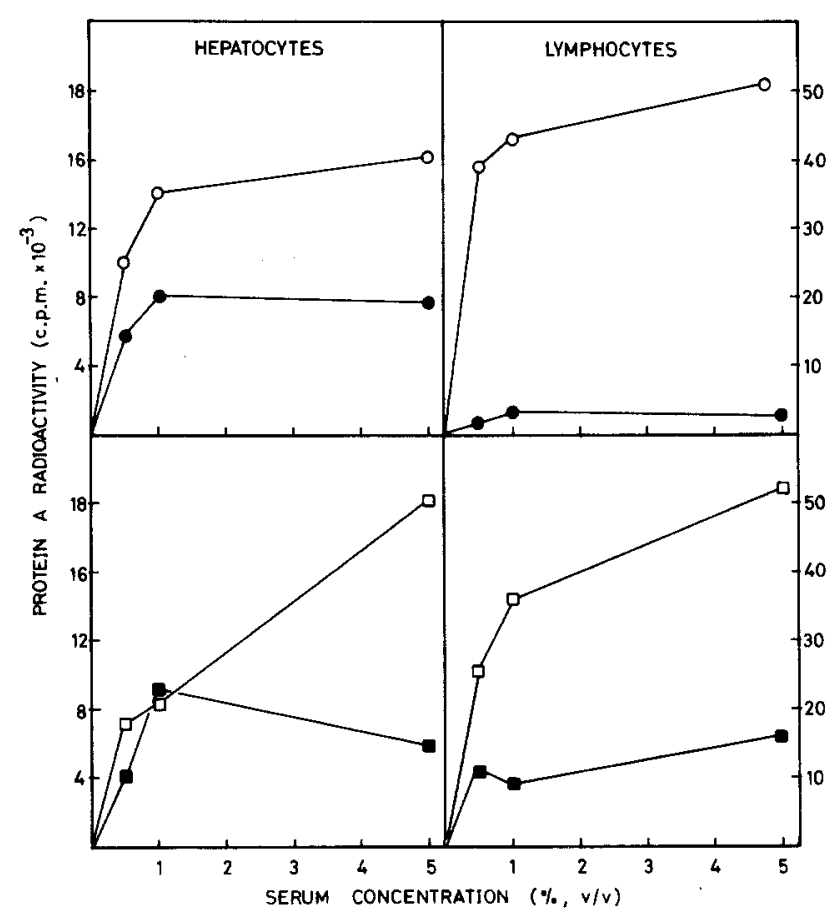

Fig. 3. Binding of ${ }^{125} \mathrm{I}$-Protein A to hepatocytes and spleen lymphocytes after exposure to various concentrations of rabbit antisera raised against rat spleen lymphocytes $(0-0)$, rat liver plasma membranes $(-\mathbf{-})$, rat islet cells $(\square-\square)$ or $o b / o b$-mouse islet cells $(\mathbf{\square}-\mathbf{\square})$. Suspensions of hepatocytes $\left(2-4 \times 10^{6}\right.$ cells per tube) or spleen lymphocytes $\left(0.5-2 \times 10^{6}\right.$ cells per tube werc incubated with serum, washed by centrifugation and finally incubated with ${ }^{125}$ I-Protein A. All values have been corrected for the binding induced by non-immune rabbit serum. Mean values of $2-3$ experiments

islet cells exposed to antiserum were incubated with non-radioactive Protein A (Fig. 5). Binding of ${ }^{125} \mathrm{I}$ Protein A was maximally inhibited at concentrations of Protein A higher than $0.1 \mu \mathrm{g}$. Scatchard analysis of the displacement curve shown in Figure 5 allowed an estimate of the amount of Protein A bound per cell. On rat islet cells exposed to $0.5 \%(\mathrm{v} / \mathrm{v})$ absorbed rat islet cell antiserum this method identified approximately 3-4 $\times 10^{4}$ Protein A-binding sites per cell.

\section{Discussion and Conclusions}

This study demonstrates that antibodies reactive with the cell surface of rat islet cells are induced when rabbits are immunised with suspensions of rat or mouse islet cells. Despite limitations in the availability of cells, antisera were obtained by an initial injection of viable cells into the popliteal lymph nodes followed by three intravenous injections of cells. The total number of cells which each rabbit received was approximately 2-3 $310^{6}$. Antibodies could be 


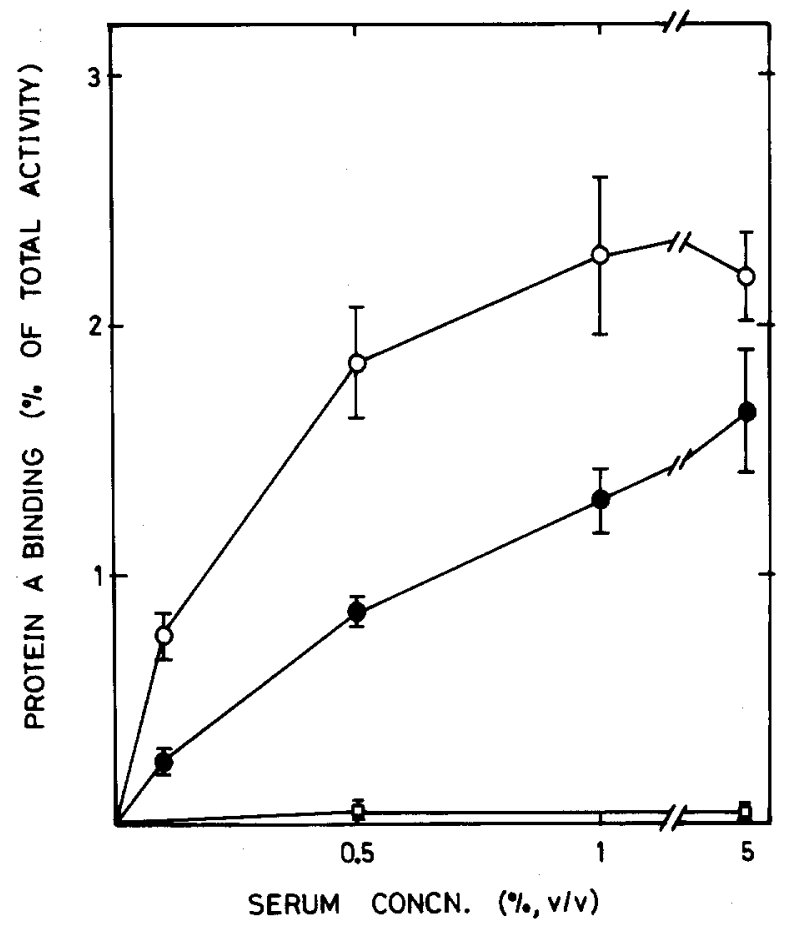

Fig. 4. Binding of ${ }^{125} \mathrm{I}$-Protein $\mathrm{A}$ to rat islet cells exposed to rabbit anti-rat islet cell antiserum, unabsorbed $(O-O)$ or absorbed (-) to spleen lymphocytes and hepatocytes. The binding induced by incubating cells in non-immune rabbit serum is also shown $(\square-\square)$. Mean values \pm SEM for 4-6 different experiments

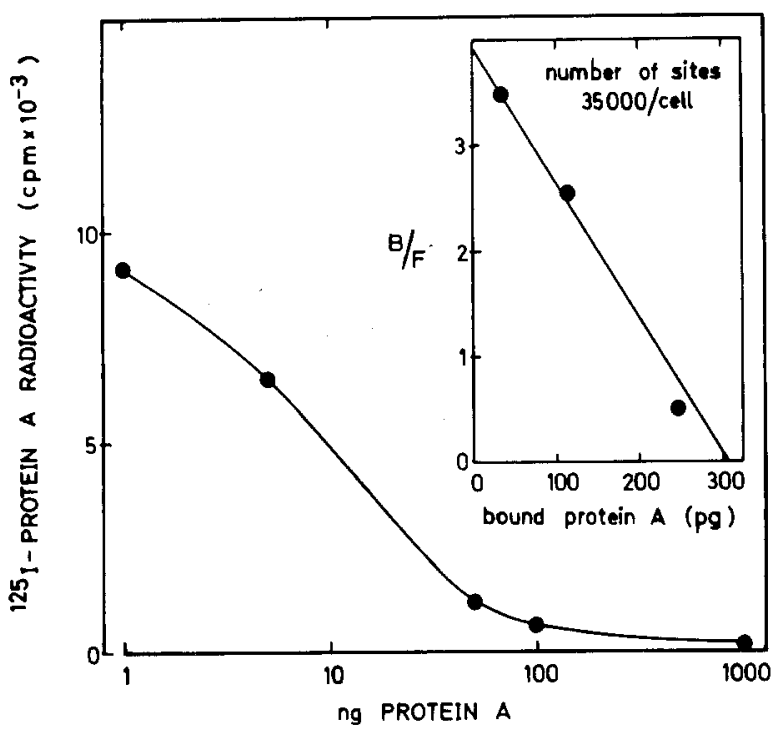

Fig. 5. Binding of ${ }^{125}$ I-Protein A to rat islet cells in a competition assay with non-radioactive Protein $\mathrm{A}$. Suspensions of rat islet $\left(10^{5}\right.$ cells) were incubated with $0.5 \%(\mathrm{v} / \mathrm{v})$ rabbit anti-rat islet cell antiserum extensively absorbed to spleen lymphocytes and hepatocytes. After washing by centrifugation the cells were exposed to various concentrations of non-radioactive Protein $A$ before the final incubation with ${ }^{125}$ I-Protein A. Mean values of 2 experiments. The inset shows a Scatchard plot analysis of the data to estimate the number of available Protein A-binding sites demonstrated by indirect immunofluorescence or by a sensitive Protein A-binding assay which we have developed. Antibodies to insulin were not detected. While the two different rabbit anti-islet cell sera showed positive surface staining on monolayer of rat islet cells they were negative when tested by indirect immunofluorescence on frozen sections of rat pancreas, kidney and liver as well as human pancreas, stomach and thyroid (Bottazzo, personal communication). In addition, high titre glucagon [23], insulin antisera, or sera from diabetic patients having high titres of circulating insulin antibodies [8] did not induce cell surface immunofluorescence on rat islet cells. As might be expected with a cross-species immunisation, the anti-islet antisera reacted with hepatocytes and spleen cells which indicates that some non-organ specific antibodies were obtained (in addition to organ specific antibodies). However, after extensive absorption with both hepatocytes and spleen cells, the antiserum still contained antibodies reactive with the rat islet cells. Our absorption experiments clearly demonstrate that it is possible to prepare specific antisera to islet cells in heterologous species. This conclusion was validated by means of the vigorous titration of residual ${ }^{125}$ I-Protein A-binding in absorbed sera until control levels were reached when retested on spleen cells and hepatocytes.

The technique of absorbing out antibodies reactive with other cells may, however, remove common antibodies directed to functionally important membrane components. The rabbit anti-liver cell membrane antiserum used in our study is known to inhibit the activity of 5'-nucleotidase, but not that of phosphodiesterase in isolated liver cell plasma membranes (Evans, personal communication, [24]). In addition to binding to hepatocytes we found that this antiserum also reacted with islet cells as well as spleen lymphocytes. The presence of a specific antibody against 5'-nucleotidase, generally regarded as an ectoenzyme on cells $[25,26]$ including the islet cells [11], remains to be elucidated. The availability of monospecific antisera to proteins associated with the cell membrane should, however, prove useful in attempts to characterise the molecular composition of the plasma membrane. This approach has been highly successful in biochemical studies on transplantation antigens $[27,28]$. In order to understand the possible pathophysiological importance of islet cell antibodies, it will be important to further characterise such $B$ cell antigens and their reactivity with the autogenous antibodies which are present in insulindependent diabetes.

Acknowledgements. The authors are indebted to Dr. W. H. Evans, National Institute for Medical Research, Mill Hill, London, for a 
generous supply of anti-liver cell plasma membrane antiserum and to Dr. Howard S. Tager who kindly donated glucagon antiserum. Portions of this work were supported by grants from the USPHS (AM-17046 and AM-20595).

\section{References}

1. Bottazzo GF, Florin-Christensen A, Doniach D (1974) Islet cell antibodies in diabetes mellitus with autoimmune polyendocrine deficiencies. Lancet II: 1279-1283

2. MacCuish AC, Jordan J, Campbell CJ, Duncan LJP, Irvine WJ (1974) Antibodies to islet-cells in insulin-dependent diabetics with coexistent autoimmune disease. Lancet II: 1529-1533

3. Lendrum R, Walker G, Gamble DR (1975) Islet-cell antibodies in juvenile diabetes mellitus of recent onset. Lancet I: $880-883$

4. Irvine WJ, McCallum CJ, Gray RS, Campbell GJ, Duncan LJP, Farquhar JW, Vaughan H, Morris PJ (1977) Pancreatic islet cell antibodies in diabetes mellitus correlated with the duration and type of diabetes, coexistent autoimmune disease, and HLA-type. Diabetes 26: 138-147

5. Irvine WJ, Gray RS, McCallum CJ (1976) Pancreatic islet-cell antibody as a marker for asymptomatic and latent diabetes and prediabetes. Lancet II: 1097-1102

6. Del Prete GF, Betterle C, Padovan D, Erle G, Toffolo A, Bersahi G (1977) Incidence and significance of islet-cell autoantibodies in different types of diabetes mellitus. Diabetes 26 : 909-915

7. Irvine WJ, Gray RS, McCallum CJ, Duncan LJP (1977) Clinical and pathogenic significance of pancreatic islet-cell antibodies in diabetics treated with oral hypoglycemic agents. Lancet I: $1025-1027$

8. Lernmark $\AA$, Freedman ZR, Hofmann C, Rubenstein AH, Steiner DF, Jackson RL, Winter RJ, Traisman HS (1978) Islet cell surface antibodies in juvenile diabetes mellitus. $\mathrm{N}$ Engl $\mathrm{J}$ Med 299: 375-380

9. Moskalewski S (1965) Isolation and culture of the islets of Langerhans of the guinea pig. Gen Comp Endocrinol 5: 342-351

10. Lacy PE, Kostianovsky M (1967) Method for the isolation of intact islets of Langerhans from the rat pancreas. Diabetes 16: $35-42$

11. Lernmark $\AA$ (1974) The preparation of, and studies on, free cell suspensions from mouse pancreatic islets. Diabetologia 10: $431-438$

12. Lernmark $\AA$, Nathans A, Steiner DF (1976) Preparation and characterisation of plasma membrane-enriched fractions from rat pancreatic islets. J Cell Biol 71: 606-623

13. Böyum A (1968) Isolation of mononuclear cells and granulocytes from human blood. Scand J Clin Lab Invest 21: 77-89

14. Chan SJ (1977) Ph. D. dissertation, University of Chicago

15. Goudie RB, Horne CHW, Wilkinson PC (1966) A simple method for producing antibody specific to a single selected diffusible antigen. Lancet II: 1224-1226

16. Baumstark JS, Laffin RJ, Bardawil WA (1964) A preparative method for the separation of $7 \mathrm{~S}$ gamma globulin from human serum. Arch Biochem Biophys 108: 514-522

17. Hjelm H, Hjelm K, Sjöquist J (1972) Protein A from Staphylococcus aureus. Its isolation by affinity chromatography and its use as an immunosorbent for isolation of immunoglobulins. FEBS Lett 28: 73-76

18. Morgan CR, Lazarow A (1963) Immunoassay of insulin: two antibody system. Plasma insulin levels of normal, subdiabetic and diabetic mice. Diabetes 12: 115-126

19. Freychet P, Roth J, Neville DM (1971) Monoiodo-insulin: demonstration of its biological activity and binding to fat cells and liver membranes. Biochem Biophys Res Commun 43: $400-408$

20. Welsh KI, Dorval G, Wigzell H (1975) Rapid quantitation of membrane antigens. Nature 254: 67-69

21. Brown JP, Klitzman JM, Hellerström KE (1977) A microassay for antibody binding to tumor cell surface antigens using ${ }^{125} I_{-}$ labelled protein A from Staphylococcus aureus. J Immunol Methods 15: 57-66

22. Zeltzer PM, Seeger RC (1977) Microassay using iodinated protein A from Staphylococcus aureus for antibodies bound to cell surface antigens of andherent tumor cells. J Immunol Methods 17: 163-175

23. Tager HS, Hohenboken M, Markese J (1977) High titre glucagon antisera. Endocrinology 100: 367-372

24. Gurd JW, Evans WH (1974) Distribution of liver plasma membrane 5 '-nucleotidase as indicated by its reaction with anti-plasma membrane serum. Arch Biochem Biophys 164: 305-311

25. DePierre JW, Karnovsky ML (1974) Ecto-enzyme of granulocytes: 5'-nucleotidase. Science 183: 1096-1098

26. DePierre JW, Karnovsky ML (1974) Ecto-enzymes of the guinea pig polymorphonuclear leucocyte. I. Evidence for an ecto-adenosine monophosphatase, -adenosine triphosphatase, and p-nitrophenyl phosphatase. J Biol Chem 249: 7111-7120

27. Schwartz BD, Nathenson SG (1971) Isolation of H-2 alloantigens solubilised by the detergent NP-40. J Immunol 107: 1363-1367

28. Schwartz BD, Kask AM, Sharrow SO, David CS, Schwartz RH (1977) Partial chemical characterisation of Ia antigens derived from murine lymphocytes. Proc Natl Acad Sci USA 74: 1195-1199

Received: November 19, 1979 , and in revised form: June 3, 1980

Åke Lernmark, M. D.

Hagedorn Research Laboratory

Niels Steensensvej 6

DK-2820 Gentofte

Denmark 